\title{
Obtaining a Gypsum-Cement Blend, to Be Used as Filling, with Low Hardening Temperature
}

\author{
Gabriela Abad-Farfán ${ }^{1}$, Tito Fernando Muñoz-Cuenca², Paúl Bolivar Torres-Jara ${ }^{1}$, \\ Efrén Vázquez-Silva ${ }^{1, *}$ \\ ${ }^{1}$ Facultad de Ingeniería Mecánica, Universidad Politécnica Salesiana, Cuenca, República del Ecuador \\ ${ }^{2}$ TUGALT S. A. Cuenca, República del Ecuador
}

\section{Email address:}

gabadf@ups.edu.ec (G. Abad-Farfán), tmunoz@graiman.com (T. F. Muñoz-Cuenca), ptorresj@ups.edu.ec (P. B. Torres-Jara), evazquez@ups.edu.ec (E. Vázquez-Silva)

${ }^{*}$ Corresponding author

\section{To cite this article:}

Gabriela Abad-Farfán, Tito Fernando Muñoz-Cuenca, Paúl Bolivar Torres-Jara, Efrén Vázquez-Silva. Obtaining a Gypsum-Cement Blend, to Be Used as Filling, with Low Hardening Temperature. Advances in Materials. Vol. 6, No. 6, 2017, pp. 115-121.

doi: 10.11648/j.am.20170606.12

Received: September 7, 2017; Accepted: September 26, 2017; Published: November 7, 2017

\begin{abstract}
When a beam, made of material whose properties would be affected at temperatures above $37^{\circ} \mathrm{C}$ and with irregular geometry at its ends, is subjected to a bending test; it is necessary to guarantee the stability of its support points to achieve success in the execution of the test. This paper presents a study on the properties of a particular composite material that is used as a filling for certain hollow supports with the aim to provide stability to the ends of the beam when the load is applied. Although the mixture employed reacts exothermically, it does not exceed the maximum temperature level above which the mechanical properties of the constituent material of the beam would be affected. In addition, the strength of the mixture is such that it is able to withstand the compression stresses that are generated during the test.
\end{abstract}

Keywords: Hardness, Stress Measurements, Composites

\section{Introduction}

Nowadays different types of materials have been developed in order to satisfy the needs of industrial and scientific communities, as well as the population in general; and at the same time to stimulate the development of engineering fields. The study of the properties of the materials in Mechanics is of great importance, because it delimits the area of performance of the material and defines the characteristics that differentiate them from the rest of materials.

The knowledge of the behavior and the mechanical properties of bones enables the construction of prostheses and provides solutions for designing mechanisms of locomotion [1].

Temperature significantly affects almost all the properties of materials. An increase in temperature may alter the behavior of materials (consult [2], for example). The specific case of aluminum foil $1050 \mathrm{~A}$ can be analyzed, as an example of the previous affirmation, in [3]. Materials have less resistance and greater ductility at high temperatures [2]. Just as biological materials in general, the mechanical properties of bones are affected due to the effect of temperature fluctuations. The temperature surrounding the bone can cause significant changes in its Young's modulus [4]. Long bones have a complex characterization because of its geometry and the elements that make them up [5].

When flexural tests are performed on long bones a problem occurs when applying the load due to lack of grasping of bones onto the testing equipment. The geometry of the bones ends is irregular, that is why filling material has been used as supports, such as Wood's metal, in order to guarantee a correct fixing [6]. The results obtained after using Wood's metal as a fixing element were not entirely satisfactory because the melting point of this material (70 degrees Celsius) was not considered, which in fact does alter 
the properties of the bones.

Materials such as Wood's metal, polyester resin and gypsum, have advantages such as quickly hardening and resistance in filling applications for cavities that enable testing materials of complex geometry. But they have a disadvantage due to its temperature of hardening. On the other hand, a material such as Portland cement, which has minimum fluctuations of temperature in its hydration, has disadvantages due to the time it takes to harden.

The preservation, hydration and temperature of a biological structure like a bone are important factors in order to determine its mechanical properties. Despite being impractical, an appropriate mechanical test of bones should be performed at a temperature of 37 degrees Celsius. Testing bones at room temperature, 23 degrees Celsius, would increase Young's modulus, but not in a considerable amount [4].

Therefore, it was decided to obtain a filling material (mixture of dental gypsum and Portland cement) to ensure adequate grip of the long bones that undergo flexural tests. Since the human tibia is a long bone, it may resist a load of $11.76 \mathrm{KN}$ in flexural tests [1]. These type of tests are necessary to characterize these bones from a mechanical point of view.

For some time the study of composite materials has occupied a relevant place in general investigations and in the engineering field in particular. The preservation of the environment, sustainable development and the phenomena associated with climate change play an important role in the rise of the study and development of this type of materials. Thus, a very important direction of work in this regard is the production and study of biodegradable composite materials (see, for example, [17]). It is also studied how to reuse waste materials and obtain new biocomposites, [18]. Another important direction in this type of research is the study of electrical properties, taking into account the possible technical applications of the new compounds; in this case we can refer to the work [19]. And the mechanical properties of such materials have also been studied in terms of their response to transformations or actions such as machining [20], [21].
On the other hand, the bone material has also been mechanically studied because of the interest and importance of the development of implants and prosthesis intended to improve the quality of life of people who have suffered a bone injury. In this case we can cite mechanical impact tests [22] and rigidity tests from a four-point flexural assay [23]. In these two cases the tests are not performed by supporting the bone at its ends; and no references have been found for testing with this type of fixation. When attempting such a test, the irregular shape of the heads of the long bones is a difficulty, so an attachment is required to fit the ends of the bone in such a way that allows stability when applying load. In the New Materials and Processes of Transformation Research Group (GIMAT- acronym in Spanish) of the Universidad Politécnica Salesiana in Ecuador, the support molds were created for the realization of this type of tests, however, a filling material was needed with the properties described above. Such a need could not be covered with the available and of great use at technological and industrial level composite materials.

\section{Materials and Methods}

It was suggested the design and evaluation of a composite material by the mixture of dental gypsum and white Portland cement, with the use of the statistical technique Analysis of Variance (ANOVA), in order to obtain filling material that does not have significant variations of temperature in its hardening, that hardens in a relatively short time and that possesses a determined resistance.

\subsection{Proportions of Dental Gypsum and White Cement}

Three types of dental gypsum of the Whip Mix brand, distributed by Krobalto C. A Company, were applied. The properties of these products are detailed in the catalogue [8]. In the Table 1 is present the dental gypsum products applied in this study and it was possible to see that the amount of water used, or the W/P relation in each type of mixture, will depend on the type of dental gypsum being used [7].

Table 1. Dental gypsum that were used.

\begin{tabular}{lll}
\hline Product & Type & W/P $[\mathbf{m l} / \mathbf{g}]$ \\
\hline Orthodontic Gypsum & Type II- Gypsum for printing & 0,50 \\
Quickstone & Type III-Gypsum Stone & 0,35 \\
Silky Rock & Type IV-High resistance gypsum stone & 0,35 \\
\hline
\end{tabular}

The white cement used in the mixture is Portland type I ASTM C-150 NTP 334.009, produced by COMACSA mining company. The water/cement relation used for the pure white cement, without any gypsum, is 0.50 since it is a typical relation for cements of medium resistance [9].

To observe the variation of the properties being studied in the gypsum-cement mixture, the following gypsum-cement proportions were used respectively: 100:0; 70:30; 50:50; 30:70 and 0:100.

\subsection{Maximum Compression Load Test}

This magnitude is determined by applying, to a test piece, a load that increase continuously until it breaks [10]. According to the ASTM C472 norm, the molds for making the test pieces should be cubic with $50.8 \mathrm{~mm}$ edge, made of a non-corrosive and rigid material to avoid dispersion [11]. To determine this property, $1 \mathrm{~mm}$ thick metal foil molds with an internal edge of $50.8 \mathrm{~mm}$ were used (Figure 1). 


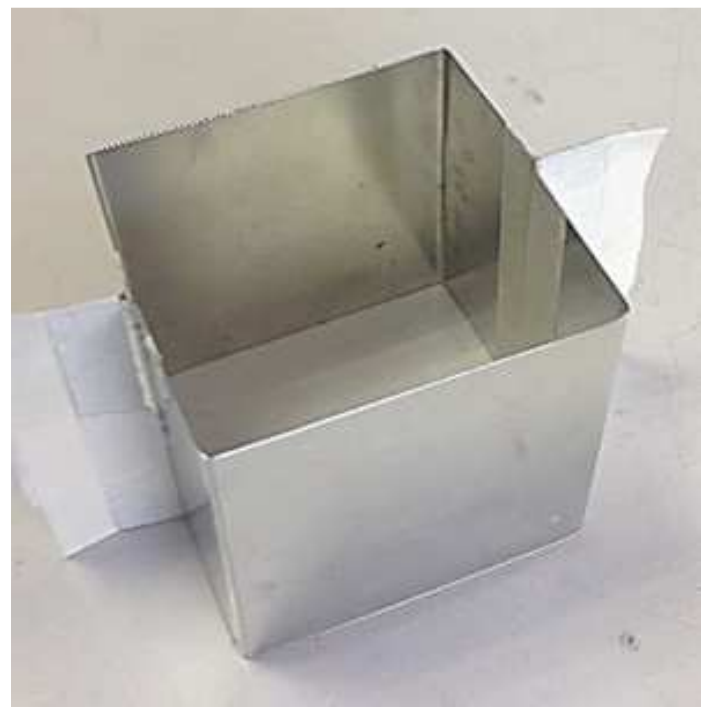

Figure 1. Metal foil mold used to obtain test pieces.

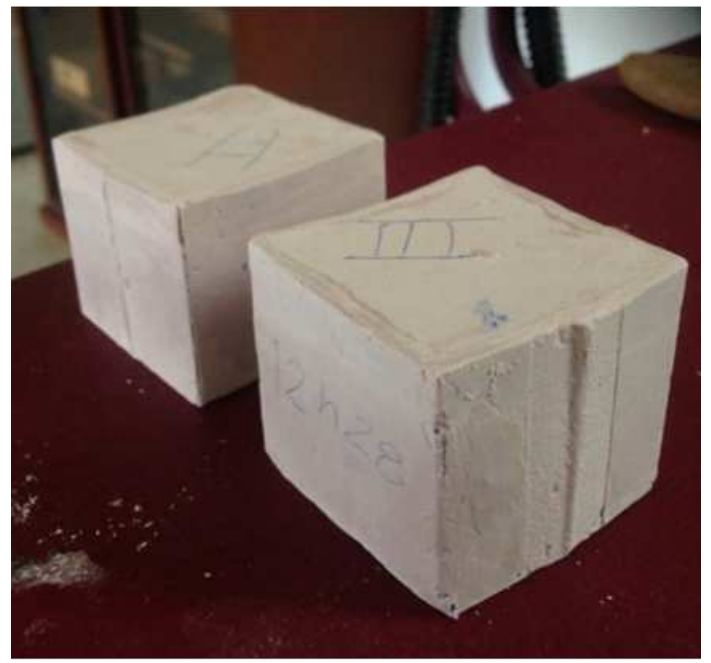

Figure 2. Test pieces obtained from the cubic molds.

In Figure 2 is shown two of the pieces used for the tests which were obtained from the molds designed for such purpose. The maximum compression load test was carried out in the METROCOM 200KN universal test machine which is located in our university's destructive testing laboratory. The load was applied at a continuous speed of $1 \mathrm{~mm} / \mathrm{s}$ and without impact [11]. The test was conducted two hours after the mixture was completely poured into the cubic mold. 5 tests were performed for each mixture of dental gypsum and white cement, since it is the minimum number of recommended measurements in the treatment of a completely random experiment [12].

\subsection{Hardening Time Test and Determination of the Maximum Temperature}

The method of increasing temperature to determine the hardening time or hydration time is based on the measurement of the maximum temperature increase of gypsum or gypsum concrete. This increase in temperature is caused by the effect of calcium sulfate hemihydrate on contact with water to form calcium sulfate dihydrate. It is assumed that the maximum increase in temperature is consistent with the completion of the reaction [11].

The variation of temperature was recorded during 120 minutes in a fixed position by means of a K-type thermocouple probe (range: a) of an OMEGA CL27 calibrator-thermometer, which has an accuracy of $\pm 0,3^{\circ} \mathrm{C}$. In Figure 3 is shown the fixed position measurement method used in all mixtures. As shown in Figure 4, the sensor was positioned at the center of the cubic test piece, i.e. $25.4 \mathrm{~mm}$ from its surfaces.

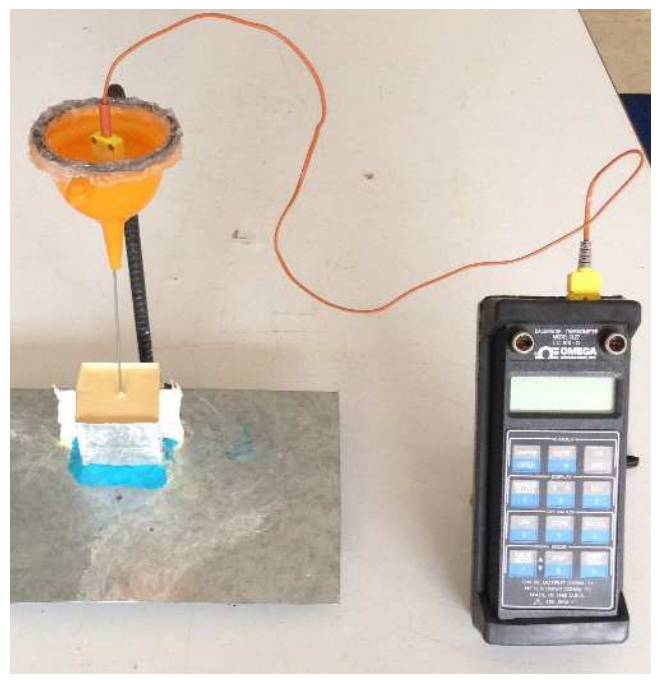

Figure 3. Method of temperature measurement in mixtures.

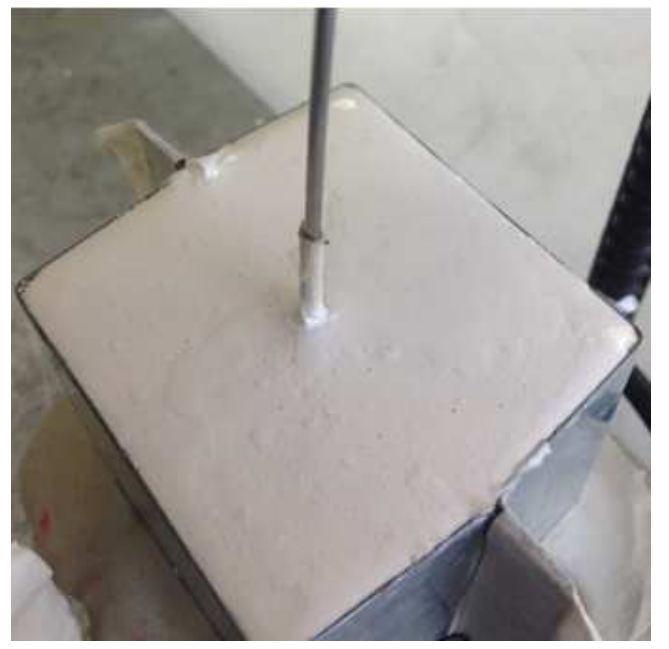

Figure 4. Position of the sensor for temperature measurement.

As in the maximum compression load test, 5 tests were carried out for each mixture of dental gypsum and white Portland cement. These tests were carried out in the destructive testing laboratory in university's branch campus in Cuenca with an average room temperature of $15.67^{\circ} \mathrm{C}$ [13]. The dry mixing of dental gypsum powder and white cement was performed in time intervals of 1 minute; and during the same amount of time the water was subsequently added. Measurements were recorded after all the mixture was completely poured into the mold. 


\subsection{Behavior's Comparison of the Properties of Interest (Experimental Measurements) for Each Mixture, by Means of Analysis of Variance}

Three modalities of ANOVA were carried out to determine the most significant variable in the mixture of dental gypsum and white cement. In the first mode of ANOVA (ANOVA $1^{\text {a }}$ ) the significance of the maximum compression load, maximum temperature and hardening time properties were analyzed for the different proportions considered of the mixture made up by a single type of dental gypsum and white cement.

In the second mode of ANOVA (ANOVA $1^{\mathrm{b}}$ ) the significance of the properties of the maximum compression load, the maximum temperature and hardening time were studied in the same proportion of the mixture for the three types of dental gypsum and white Portland cement that were considered. In the third mode of ANOVA, a comparison of two factors was carried out and conclusions were reached on the significance of the properties of maximum compression load, maximum temperature and hardening time in different proportions of the mixture of dental gypsum and white cement; confirming the results obtained in ANOVA $1^{\mathrm{a}}$ and ANOVA $1^{\mathrm{b}}$.

\section{Results and Discussion}

The METROCOM 200KN universal testing machine issued reports where the load-deformation behavior curve can be observed, in addition to obtaining the maximum compression load. In the Table 2 are summarized the results of the tests carried out on each of the mixtures (in this and the following tables we are using the nomenclature: $\mathrm{Q}-$ Quickstone gypsum; SR - Silky Rock gypsum; OP Orthodontic gypsum and C - White cement)

Table 2. Summary of maximum compression loads.

\begin{tabular}{|c|c|c|c|c|c|c|}
\hline \multirow[b]{2}{*}{ Blend (\%) } & \multicolumn{6}{|c|}{ Maximum Compression Load [KN] } \\
\hline & Test I & Test II & Test III & Test IV & Test V & Mean \\
\hline $100 \mathrm{Q}-0 \mathrm{C}$ & 45,42 & 44,39 & 42,05 & 44,88 & 42,34 & 43,82 \\
\hline $100 \mathrm{SR}-0 \mathrm{C}$ & 51,85 & 48,64 & 48,94 & 50,66 & 48,74 & 49,77 \\
\hline $100 \mathrm{OP}-0 \mathrm{C}$ & 26,69 & 21,46 & 23,06 & 28,26 & 25,86 & 25,07 \\
\hline $70 \mathrm{Q}-30 \mathrm{C}$ & 35,73 & 32,47 & 33,13 & 28,8 & 37,39 & 33,50 \\
\hline $70 \mathrm{SR}-30 \mathrm{C}$ & 29,72 & 35,28 & 31,98 & 34,23 & 28,65 & 31,97 \\
\hline $50 Q-50 \mathrm{C}$ & 24,32 & 25,44 & 26,17 & 20,2 & 22,24 & 23,67 \\
\hline $50 \mathrm{SR}-50 \mathrm{C}$ & 21,63 & 22,85 & 21,05 & 23,15 & 22,33 & 22,20 \\
\hline $50 \mathrm{OP}-50 \mathrm{C}$ & 11,78 & 13,34 & 11,78 & 12,68 & 10,14 & 11,94 \\
\hline $30 \mathrm{Q}-70 \mathrm{C}$ & 11,29 & 11,68 & 11,51 & 10,88 & 8,54 & 10,78 \\
\hline $30 \mathrm{SR}-70 \mathrm{C}$ & 9,3 & 9,57 & 10,6 & 9,4 & 9,62 & 9,70 \\
\hline $30 \mathrm{OP}-70 \mathrm{C}$ & 4,42 & 4,77 & 5,29 & 4,85 & 5,85 & 5,04 \\
\hline
\end{tabular}

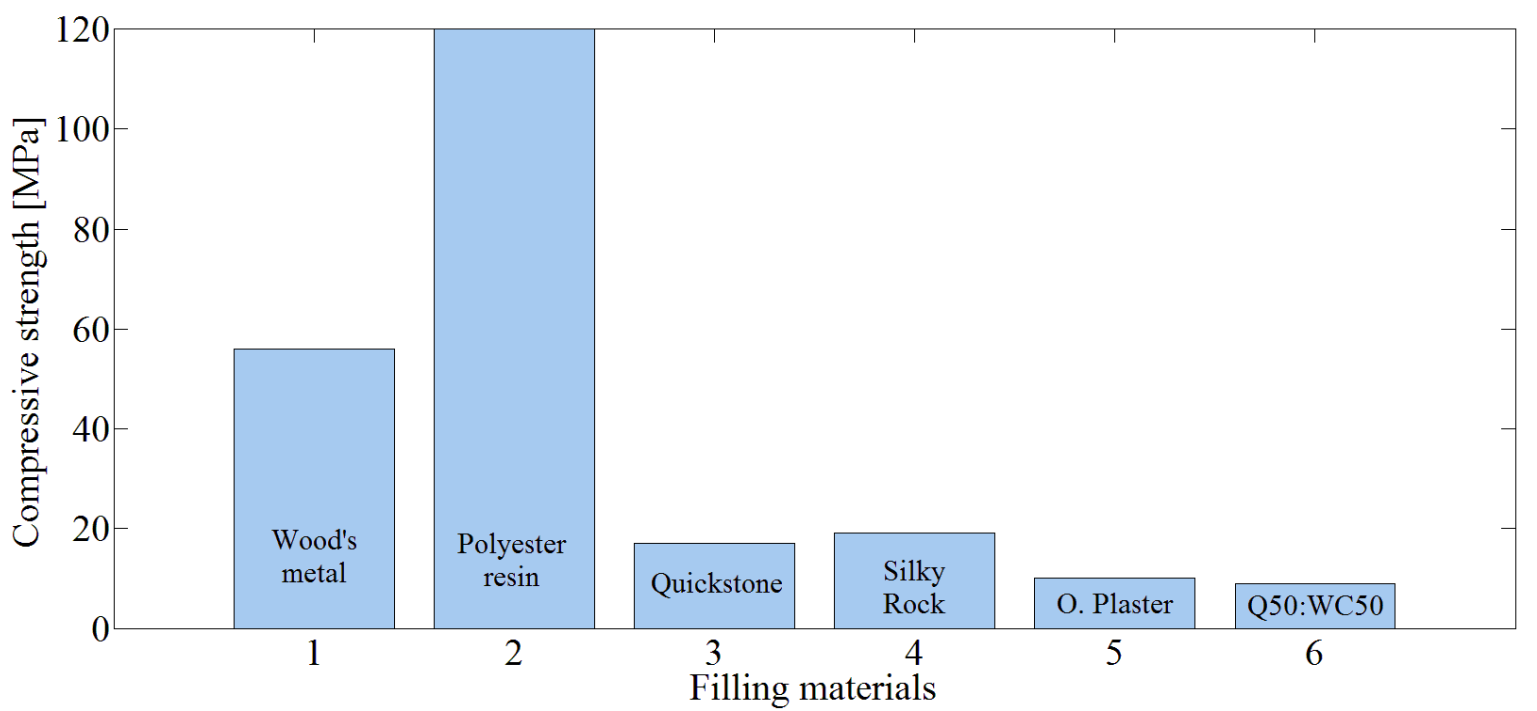

Figure 5. Resistance to compression of various filling materials.

The OMEGA CL27 calibrator-thermometer provided temperature data while the mixture was hardening or undergoing the reaction. In Tables 3 and 4 were summarized the maximum temperatures and hardening time of the different mixtures, respectively. 


\begin{tabular}{|c|c|c|c|c|c|c|}
\hline \multirow[b]{2}{*}{ Blend (\%) } & \multicolumn{6}{|c|}{ Maximum Temperature $\left[{ }^{\circ} \mathrm{C}\right]$} \\
\hline & Test I & Test II & Test III & Test IV & Test $\mathrm{V}$ & Mean \\
\hline $100 \mathrm{Q}-0 \mathrm{C}$ & 48 & 45,6 & 49,3 & 48,6 & 49,1 & 48,12 \\
\hline $100 \mathrm{SR}-0 \mathrm{C}$ & 48,5 & 46,3 & 48,5 & 48,1 & 51,2 & 48,52 \\
\hline $100 \mathrm{OP}-0 \mathrm{C}$ & 39,9 & 37,6 & 37,4 & 39,3 & 39,3 & 38,7 \\
\hline $70 \mathrm{Q}-30 \mathrm{C}$ & 41,1 & 42,5 & 44,1 & 41,1 & 44,4 & 42,64 \\
\hline $70 \mathrm{SR}-30 \mathrm{C}$ & 42,6 & 41,6 & 42,6 & 40,6 & 40,6 & 41,6 \\
\hline $70 \mathrm{OP}-30 \mathrm{C}$ & 35,1 & 35,7 & 36 & 36,7 & 36,9 & 36,08 \\
\hline $50 \mathrm{Q}-50 \mathrm{C}$ & 36,8 & 38,1 & 38,2 & 33,7 & 38,8 & 37,12 \\
\hline $50 \mathrm{SR}-50 \mathrm{C}$ & 34,6 & 36,3 & 35,7 & 36,6 & 36,3 & 35,9 \\
\hline $50 \mathrm{OP}-50 \mathrm{C}$ & 31,2 & 31,5 & 30,1 & 30,6 & 31,9 & 31,06 \\
\hline $30 \mathrm{Q}-70 \mathrm{C}$ & 28,5 & 29,6 & 27 & 28,2 & 29,2 & 28,5 \\
\hline $30 \mathrm{SR}-70 \mathrm{C}$ & 29,6 & 28,3 & 26,2 & 27,8 & 27,7 & 27,92 \\
\hline $30 \mathrm{OP}-70 \mathrm{C}$ & 27,2 & 26,4 & 27,5 & 29,7 & 27,1 & 27,58 \\
\hline
\end{tabular}

In the Table 3 were shown that the lowest average hardening temperatures were obtained by using the Orthodontic Plaster in all its proportions 100: $0\left(38.7^{\circ} \mathrm{C}\right)$; $70: 30\left(36.08^{\circ} \mathrm{C}\right) ; 50: 50\left(31.6^{\circ} \mathrm{C}\right) ; 30: 70\left(27.58^{\circ} \mathrm{C}\right)$ in the mixture. In Figure 6 you can see the comparison between the maximum hardening temperatures for other filling materials [16] and the material suggested in the present study.

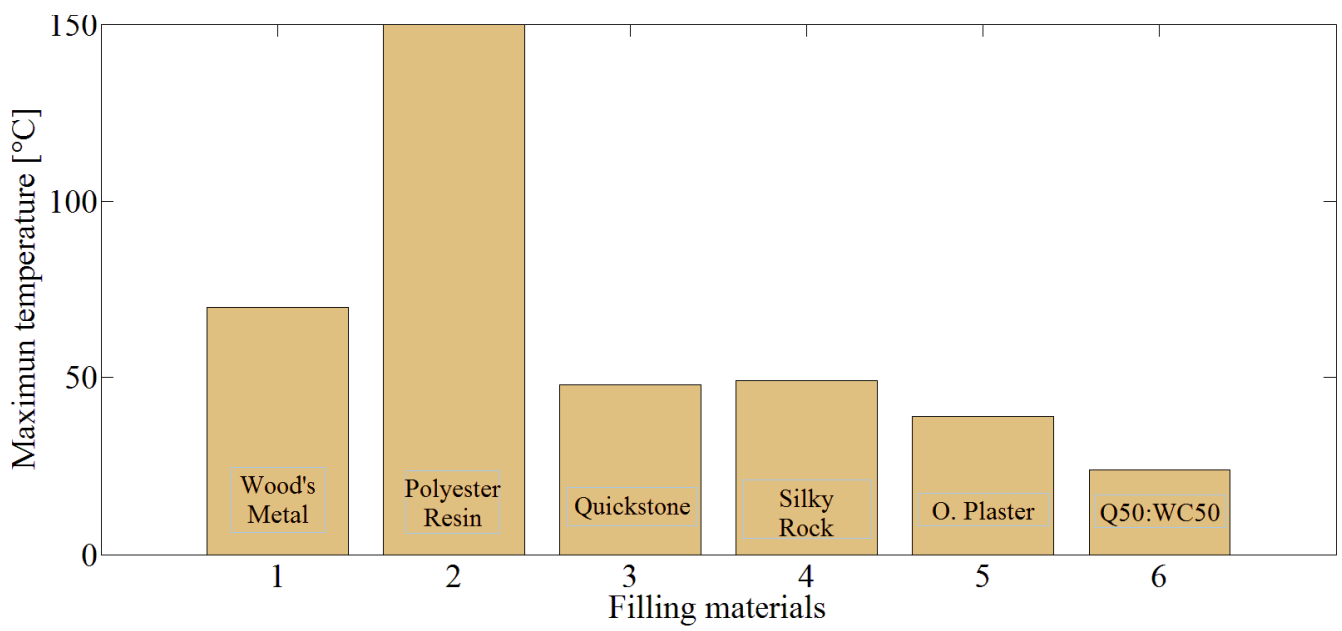

Figure 6. Maximum temperature for several filling materials.

In the Table 4 it is demonstrated that the best average hardening time in the 100: 0 proportion was obtained by using Quickstone Plaster in the mixture (30.8 $\mathrm{min})$. On the other hand, the best average hardening times with Orthodontic Plaster were obtained in proportions 70:30 (22.8 $\min )$, 50:50 (21.8 $\mathrm{min})$ and 30:70 (20 $\mathrm{min})$

Table 4. Summary of hardening time.

\begin{tabular}{|c|c|c|c|c|c|c|}
\hline \multirow[b]{2}{*}{ Blend $(\%)$} & \multicolumn{6}{|c|}{ Hardening Time [minutes] } \\
\hline & Test I & Test II & Test III & Test IV & Test $\mathrm{V}$ & Mean \\
\hline $100 \mathrm{Q}-0 \mathrm{C}$ & 30 & 34 & 32 & 28 & 30 & 30,8 \\
\hline $100 \mathrm{SR}-0 \mathrm{C}$ & 39 & 41 & 40 & 40 & 37 & 39,4 \\
\hline $100 \mathrm{OP}-0 \mathrm{C}$ & 52 & 50 & 55 & 53 & 53 & 52,6 \\
\hline $70 \mathrm{Q}-30 \mathrm{C}$ & 38 & 38 & 39 & 37 & 39 & 38,2 \\
\hline $70 \mathrm{SR}-30 \mathrm{C}$ & 63 & 63 & 62 & 64 & 68 & 64 \\
\hline $70 \mathrm{OP}-30 \mathrm{C}$ & 23 & 24 & 22 & 22 & 23 & 22,8 \\
\hline $50 \mathrm{Q}-50 \mathrm{C}$ & 29 & 29 & 27 & 31 & 28 & 28,8 \\
\hline $50 \mathrm{SR}-50 \mathrm{C}$ & 41 & 42 & 44 & 42 & 48 & 43,4 \\
\hline $50 \mathrm{OP}-50 \mathrm{C}$ & 21 & 22 & 22 & 23 & 21 & 21,8 \\
\hline $30 \mathrm{Q}-70 \mathrm{C}$ & 25 & 24 & 26 & 25 & 24 & 24,8 \\
\hline $30 \mathrm{SR}-70 \mathrm{C}$ & 45 & 45 & 41 & 41 & 39 & 42,2 \\
\hline $30 \mathrm{OP}-70 \mathrm{C}$ & 20 & 22 & 20 & 17 & 21 & 20 \\
\hline
\end{tabular}

In the third mode of ANOVA the joint incidence of the dental gypsum type and the proportion with white Portland cement on the mixture was studied. The results of the ANOVA for the maximum temperature data of the mixture of the three types of dental gypsum with white cement in the different proportions, obtained experimentally, are listed in the Table 5. 


\begin{tabular}{llllll}
\hline Inter-subject effects test & & & & \\
\hline Independent variable: Maximum temperatura $\left[{ }^{\circ} \mathbf{C}\right]$ & & & \\
\hline Source & Type III of sum of squares & Degrees of freedom & Quadratic mean & F & Significance \\
\hline Corrected model & 2965,030 & 11 & 269,548 & 161,543 &, 000 \\
Intersection & 82043,828 & 1 & 82043,828 & 49169,752 &, 000 \\
Blend & 2426,946 & 3 & 808,982 & 484,832 &, 000 \\
Gypsum & 397,577 & 2 & 198,789 & 119,136 &, 000 \\
Blend*Gypsum & 140,507 & 6 & 23,418 & 14,035 &, 000 \\
Error & 80,092 & 48 & 1,669 & & \\
Total & 85088,950 & 60 & & & \\
Total Corrected & 3045,122 & 59 & & & \\
\hline
\end{tabular}

The obtained results allow to have a good idea about the behavior of some of the properties (maximum compressive strength, maximum hardening temperature and hardening time) of the composite material formed by cement and dental plaster. In addition, it was possible to establish an appropriate proportion of each component in the blend, so that there are satisfy the requirements for filling in the supports used in the fixation of the long bone ends for bending tests.

\section{Conclusions}

It was tested with three types of mixtures. The experimental results show that the amount of white cement used in the different mixtures affects the strength, maximum temperature and hardening time. The suitable mixture to guarantee a good fluidity is made up by Orthodontic Plaster and white cement, due to the consistency and ease for pouring.

There was a decrease in the maximum temperature when increasing the amount of white cement and decreasing the amount of dental gypsum. The mixture that presents the lowest average maximum hardening temperature value $\left(27.58^{\circ} \mathrm{C}\right)$, is the one made up by $30 \%$ of Orthodontic Plaster and $70 \%$ of white Portland cement.

The hardening times in the mixtures that have Quickstone gypsum decreased when increasing the amount of white cement, except for the 70:30 proportion, which exceeded the hardening time of the mixture without white cement. The hardening times in the mixtures that have Silky Rock gypsum increased and even exceeded the hardening time of the mixture without white cement. The hardening times in the mixtures that have Orthodontic Plaster decreased when increasing the amount of white cement. Thus, the best hardening times were obtained in Orthodontic Plaster and white Portland cement mixtures.

The mixtures of Quickstone gypsum-white cement and Silky Rock-white cement gypsum had the best results of maximum compression load.

Based on the analysis of variance and their respective multiple comparisons, the most significant variable is the maximum temperature. The proportion of white cement used in the mixture significantly reduces the maximum temperature of the mixture, even using any of the three types of dental gypsum. The more Portland white -cement in the mixture, the lower the maximum hardening temperature.

From all the aforementioned information, the most suitable mixture to be used as filling material in cavities, and one that allows successful flexural tests in long bones, is the one made up by Quickstone gypsum and white cement in the $50: 50$ proportion, since it reaches a maximum temperature of $37.12^{\circ} \mathrm{C}$, a hardening time of 28.8 minutes and a maximum compression load of $23.67 \mathrm{KN}$.

\section{Acknowledgements}

The authors are grateful for the collaboration and support provided by the New Materials and Processes of Transformation's Research Group (GIMAT- acronym in Spanish) of the Universidad Politécnica Salesiana, sede Cuenca; Ecuador.

\section{References}

[1] A. Mendoza, "Estudio de las propiedades mecánicas del sistema óseo", Ingeniería e Investigación, no. 23, pp. 14-19, 1991.

[2] M. P. Groover, Fundamentos de manufactura moderna: materiales, procesos y sistemas. Pearson Educación, 1997.

[3] J. Pérez-Ilzarbe, J. Fernández-Carrasquilla, C. Luis-Pérz, "Estudio de la variación, con el calentamiento, de las propiedades mecánicas y de la re-cristalización de la hoja fina de aluminio 1050A". Memorias XI Congreso nacional de propiedades mecánicas de sólidos. Universidad de Cádiz, pg. 115. El Bosque, Sierra de Grazalema; 9 al 12 de septiembre, Cádiz, España, 2008.

[4] S. C. Cowin and others, Bone mechanics handbook. CRC press, 2001.

[5] D. Martínez, A. Ortiz, and E. I. Ramírez, "Comportamiento mecánico de hueso femoral porcino bajo cargas a flexión". Memorias del 14 Congreso Internacional anual de la SOMIM; 17 al 19 de septiembre, Puebla, México, 2008.

[6] J. Grasa; L. A. González; M. J. Gómez-Benito; J. M. GarcíaAznar; J. A. Bea; P. J. Laborda: M. Doblaré, "Caracterización mecánica de las propiedades del tejido óseo cortical". Revista Anales de Mecánica de la Fractura, Vol. 1, Nro. 25, pp. 2328. 2008.

[7] J. F. McCabe and A. W. G. Walls, Applied Dental Materials. John Wiley \& Sons, 2013.

[8] "Yesos Dentales". Krobalto. [Online]. Available: http://krobalto.com/tienda/153-yesos-dentales. [Accessed: 05Dec-2016]. 
[9] J. R. Underwood and M. Chiuini, Structural Design: A Practical Guide for Architects. John Wiley \& Sons, 1998.

[10] S. Crespo-Escobar, Materiales de construcción para edificación y obra civil. Editorial Club Universitario, Alicante, España, 2013.

[11] B. ASTM, "C472-Standard Test Methods for Phyical Testing of Gypsum”, Gypsum Plasters and Gypsum Concrete, p. 2, 1999.

[12] H. G. Pulido, Análisis y diseño de experimentos (3a. ed.). McGraw-Hill Interamericana, 2000.

[13] M. P. Pesántez-Moyano, "Confort térmico en el área social de una vivienda unifamiliar en Cuenca-Ecuador", Universidad de Cuenca, Tesina previa a la obtención del título Diseño de Interiores, 2012. [Online]. Available: http://dspace.ucuenca.edu.ec/bitstream/123456789/393/1/tesis. pdf

[14] L. Wierzbicki, "Strength properties of the low-melting-point alloys", Journal of Achievements in Materials and Manufacturing Engineering, vol. 67, no. 1, 2014.

[15] H. Hansmann, Compendium Composites. ASM hand book on Polyester resins: ASM International: Ohio, 2003.

[16] A. Besednjak, Materiales Compuestos. Vol. 100, Univ. Politécnica de Catalunya, 2005.

[17] D. E. Rodríguez-Félix, J. M. Quiroz-Castillo, T. Del CastilloCastro, M. M. Castillo-Ortega, L. P. Ramírez-Rodríguez, D. García-Bedoya, T. Mendívil-Reynoso, "Preparación y caracterización de materiales compuestos degradables". Superficies y Vacio, vol. 28, no. 1, pp. 18-24, 2015.

[18] A. Rahhali, "Valorización de residuos queratínicos para la obtención de materiales biocompuestos". Tesis de doctorado. Escola d'Enginyeria de Terrassa. Universitat Politècnica de Catalunya. 2015 [Online]. Available:

(http://upcommons.upc.edu/handle/2117/95771)

[19] R. Salgado-Delgado, A. Olarte-Paredes, A. M. SalgadoDelgado, Z. Vargas-Galarza, E. García-Hernández, E. RubioRosas, T. López-Lara, J. B. Hernández-Zaragoza, "Caracterización eléctrica y térmica de un material compuesto de HDPE/PP y/ CB/CNT". Acta Universitaria, vol. 26, no. 2, pp. 55-62, 2016. (doi: 10.15174/au.2016.980).

[20] S. Cardona, D. Peláez, S. Betancourt, "Influencia del tipo de carga sobre el mecanizado de materiales compuestos de poliéster insaturado". Revista Colombiana de Materiales. no. 5 pp. 42-47, 2013.

[21] V. W. Álvarez -Arboleda, "Desempeño mecánico de materiales compuestos termoplásticos reforzados con fibras naturales para rotomoldeo". Proyecto de Grado. Universidad Autónoma de Occidente. Facultad de Ingeniería; Departamento de Energética y Mecánica. Santiago de Cali, Colombia, 2014. [Online]. Available: (http://hdl.handle.net/10614/6894)

[22] C. Fioretti, A. Galán, R. Moine, M. Varela, P. Varela, H. Mouguelar, S. Gigena, F. Bonino, R. Quinteros, J. Natali, "Características mecánicas dinámicas de la tibia aislada de perro sometida a prueba de impacto". Int. J. Morphol., vol. 31, no. 2. pp. 562-569, 2013.

[23] M. León, E. I. Ramírez, O. Ruiz, V. H. Jacobo, “Análisis de la rigidez de un fémur a partir del modelado de un ensayo de flexión en cuatro puntos". Memorias del XXII Congreso de la SOMIM y XIV Congreso IBEROMAT. Septiembre de 2016 CD. Mérida, Yucatán. México, 2016. 